\title{
RB1CC1 Gene
}

National Cancer Institute

\section{Source}

National Cancer Institute. RB1CC1 Gene. NCI Thesaurus. Code C88176.

This gene is involved in the modulation of both the cell cycle and autophagy. 